\title{
PENGARUH PEMBELAJARAN PRODUK KREATIF DAN KEWIRAUSAHAAN TERHADAP MINAT BERWIRAUSAHA SISWA KELAS XII KOMPETENSI KEAHLIAN TEKNIK KENDARAAN RINGAN OTOMOTIF DI SMK NEGERI 1 MANDOR
}

\author{
FY. Khosmas \\ Program Studi Pendidikan Ekonomi, Fakultas Keguruan Dan Ilmu Pendidikan, Universitas \\ Tanjungpura Pontianak \\ Email : khosmas@fkip.untan.ac.id
}

\begin{abstract}
Abstrak
Dalam penelitian ini akan diketahui pembelajaran produk kreatif dan kewirausahaan, minat berwirausaha siswa serta pengaruh pembelajaran produk kreatif dan kewirausahaan terhadap minat berwirausaha siswa. Karakteristik kewirausahaan lebih pada penguasaan kompetensi teori kewirausahaan dan pengelolaan usaha yang selaras dengan kompetensi Sekolah Menengah Kejuruan (SMK). Kurikulum 2013 lebih menekankan pada keterampilan memproduksi yang disesuaikan dengan keahlian kejuruan peserta didik. Adapun tujuan penelitian ini adalah untuk mengetahui proses pembelajaran produk kreatif dan kewirausahaan siswa dan untuk mengetahui minat berwirausaha siswa kelas XII kompetensi keahlian teknik kendaraan ringan otomotif di SMK Negeri 1 Mandor. Metode penelitian yang digunakan dalam penelitian ini adalah metode deskriptif dengan bentuk penelitian survei. Subjek dalam penelitian ini adalah siswa kelas XII Kompetensi Keahlian Teknik Kendaraan Ringan Otomotif. Peneliti menggunakan kuesioner (angket) sebagai alat pengumpul data untuk mengetahui tingkat pembelajaran produk kreatif dan kewirausahaan dan minat berwirausaha siswa kelas XII kompetensi keahlian teknik kendaraan ringan otomotif di SMK Negeri 1 Mandor. Setelah data terkumpul dan dilakukan perhitungan kuantitatif kemudian dianalisis menggunakan analisis regresi linear sederhana untuk menunjukkan bahwa terdapat pengaruh antara variabel yang diteliti. Berdasarkan hasil penelitian Pembelajaran Produk Kreatif dan Kewirausahaan berpengaruh positif terhadap Minat Berwirausaha, terlihat dari nilai koefisiennya sebesar 0.007154746 akan tetapi pengaruh Pembelajaran Produk Kreatif dan Kewirausahaan tidak berpengaruh secara signifikan terhadap Minat Berwirausaha, karena terlihat dari nilai probabilitasnya sebesar 0.955973881 lebih besar dari nilai alpha $(0,05$ / 5\%).
\end{abstract}

\section{PENDAHULUAN}

Kewirausahaan merupakan suatu wujud usaha untuk menjadikan masyarakat lebih mandiri secara ekonomi, dengan adanya kewirausahaan dapat mendorong masyarakat untuk dapat menciptakan dan menyediakan barang atau jasa yang memiliki manfaat melalui semangat untuk selalu berinovasi menemukan peluang usaha baru. Kewirausahaan adalah proses dinamik untuk menciptakan tambahan kemakmuran. Tambahan kemakmuran ini diciptakan oleh individu wirausaha yang menanggung resiko, menghabiskan waktu, dan menyediakan berbagai produk dan jasa (Alma, 2013).

Kewirausahaan dapat mendorong perubahan inovasi, kreatifitas, dan kemajuan dalam bidang ekonomi. Kewirausahaan merupakan proses penemuan atau pengembangan ide dan 
peluang untuk di jadikan usaha. Dalam berwirausaha di perlukan usaha untuk menggali dan memanfaatkan kemampuan dan potensi yang di miliki agar dapat menghasilkan sesuatu yang bermanfaat untuk orang lain dan memiliki nilai jual. Kegiatan kewirausahaan di dalamnya di perlukan invosasi dan kreatifitas yang dapat di jadikan nilai jual untuk menarik perhatian orang lain.

Sekolah merupakan tempat untuk menempuh pendidikan secara formal. Sekolah adalah tempat berlangsungnya kegiatan belajar mengajar dan tempat berinteraksi antara guru dan siswa, selain itu di sekolah juga siswa dapat mengembangkan sikap, pengetahuan dan keterampilan yang di miliki. Salah satu usaha pemerintah untuk menanamkan pengetahuan berwirausaha adalah dengan memberikan pembelajaran kewirausahaan di sekolah. Menurut Arifin (2010), pembelajaran merupakan suatu proses atau kegiatan yang sistematis dan sistemik yang bersifat interaktif dan komunikatif antara pendidik (guru) dengan siswa, sumber belajar, dan lingkungan untuk menciptakan suatu kondisi yang memungkinkan terjadinya tindakan belajar siswa. Menurut Slameto (2010) "Minat adalah suatu rasa lebih suka dan rasa ketertarikan pada suatu hal atau aktivitas, tanpa ada yang menyuruh. Minat pada dasarnya adalah penerimaan akan suatu hubungan antara diri sendiri dengan sesuatu di luar diri. Semakin kuat atau dekat hubungan tersebut, semakin besar minat". Mengembangkan minat terhadap sesuatu pada dasarnya adalah membantu siswa melihat bagaimana hubungan antara subjek yang diharapkan untuk dipelajarinya dengan dirinya sendiri sebagai individu.

Pada Sekolah Menengah Kejuruan (SMK) terdapat salah satu mata pelajaran yaitu produk kreatif dan kewirausahaan yang diajarkan pada siswa. Mata pelajaran produk kreatif dan kewirausahaan adalah mata pelajaran yang terkait secara langsung dalam penanaman pendidikan kewirausahaan kepada siswa. Mata pelajaran tersebut dapat memberikan Pemahaman dan keterampilan berwirausaha kepada siswa. Bastian dalam Wibowo (2011) menyatakan bahwa kewirausahaan bisa dihasilkan dari Learning By Doing, juga dari semangat mengambil risiko tanpa takut, bukan lewat pendidikan khusus kewirausahaan atau manajemen.

Kompetensi keahlian teknik kendaraan ringan otomotif adalah membekali peserta didik agar dapat menjadi seorang mekanik yang dapat mengelola usaha khususnya di bengkel otomotif kendaraan ringan, dapat menjual dan membukukannya dengan 
baik, serta menjadi mekanik yang kompeten dalam bidang perawatan dan perbaikan Motor, Chasis dan sistem pemindahan tenaga, dan Sistem kelistrikan.

Minat berwirausaha muncul karena adanya pengetahuan dan informasi mengenai kewirausahaan yang kemudian dilanjutkan untuk berpartisipasi secara langsung dalam rangka mencari pengalaman dan akhirnya timbul keinginan untuk memperhatikan pengalaman yang telah didapatkan tersebut. Serta mempunyai perasaan senang dan mempunyai keinginan untuk terlibat dalam kegiatan pengambilan resiko, untuk menjalankan bisnis atau usaha sendiri dengan memanfaatkan peluang-peluang bisnis yang ada, dan menciptakan bisnis baru dengan pendekatan inovatif. Minat berwirausaha tidak dimiliki dengan begitu saja, melainkan dapat dipupuk dan dikembangkan.

Berdasarkan latar belakang yang telah disampaikan,maka secara pokok penelitian ingin mengemukakan masalah penelitian yaitu: Bagaimana pembelajaran produk kreatif dan kewirausahaan siswa kelas XII kompetensi keahlian teknik kendaraan ringan otomotif di SMK Negeri 1 Mandor?, Bagaimana minat berwirausaha siswa kelas XII kompetensi keahlian teknik kendaraan ringan otomotif di SMK Negeri 1 Mandor? dan Apakah pembelajaran produk kreatif dan kewirausahaan berpengaruh terhadap minat berwirausaha siswa kelas XII kompetensi keahlian teknik kendaraan ringan otomotif di SMK Negeri 1 Mandor?

\section{METODE PENELITIAN}

Metode penelitian yang digunakan dalam penelitian ini adalah metode deskriptif dengan bentuk penelitian survei. Sugiyono (2019:6) menyatakan "Metode survei digunakan untuk mendapatkan data dari tempat tertentu yang alamiah (bukan buatan), tetapi peneliti melakukan perlakuan dalam pengumpulan data misalnya mengedarkan kuesioner, tes, wawancara terstruktur dan sebagainya".

Subjek dalam penelitian ini adalah siswa kelas XII Kompetensi Keahlian Teknik Kendaraan Ringan Otomotif. Dalam hal pengumpulan data, peneliti menggunakan kuesioner (angket) sebagai alat pengumpul data untuk mengetahui tingkat pembelajaran produk kreatif dan kewirausahaan dan minat berwirausaha siswa kelas XII kompetensi keahlian teknik kendaraan ringan otomotif di SMK Negeri 1 Mandor.

Populasi dalam penelitian ini adalah siswa-siswi Kelas XII Jurusan Teknik 
Kendaraan Ringan Otomotif di SMK

Negeri 1 Mandor. Adapun jumlah seluruh siswa-siswi sebanyak 32 orang. Setelah data terkumpul dan dilakukan perhitungan kuantitatif kemudian dianalisis menggunakan analisis regresi linear sederhana untuk menunjukkan bahwa terdapat pengaruh antara variabel yang diteliti.

Tehnik analisis data di dalam penelitian ini menggunakan analisis regresi linier sederhana, dengan rumus:

$$
\mathbf{Y}=\mathbf{a}+\mathbf{b} 1 \mathbf{X} 1
$$

Keterangan:

$\mathrm{X} 1$ = pembelajaran produk kreatif dan kewirausahaan

$\mathrm{Y}=$ minat berwirausaha siswa

$\mathrm{a}=$ nilai intercept $($ konstanta)

$\mathrm{b}=$ koefisien arah regresi

\section{HASIL DAN PEMBAHASAN}

A. Pembelajaran Produk Kreatif Dan Kewirausahaan Serta Minat Berwirausaha

Pembelajaran produk kreatif siswa dan kewirausahaan yang berlangsung di SMK Negeri 1 Mandor sudah baik di laksanakan, nilai rata-rata jawaban siswa sebesar 70,41 (kategori tinggi). Minat berwirausaha siswa kelas XII di SMK Negeri 1 Mandor sudah tinggi, nilai ratarata jawaban siswa sebesar 70,72 (kategori tinggi). Berarti minat berwirausaha siswa sudah terbangun sejak dini dan diharapkan akan dapat dikembangkan setelah menyelesaikan sekolah.

Minat berwirausaha menurut Mustofa (2014) merupakan pemusatan perhatian pada wirausaha karena adanya rasa suka dan disertai keinginan mempelajari, mengetahui dan membuktikan lebih lanjut terhadap wirausaha. Minat berwirausaha muncul karena adanya pengetahuan dan informasi mengenai kewirausahaan yang kemudian dilanjutkan untuk berpartisipasi secara langsung dalam rangka mencari pengalaman dan akhirnya timbul keinginan untuk memperhatikan pengalaman yang telah didapatkan tersebut.

B. Pengaruh Pembelajaran Produk Kreatif Dan Kewirausahaan Terhadap Minat Berwirausaha

Pembelajaran Produk Kreatif dan Kewirausahaan berpengaruh positif terhadap Minat Berwirausaha, nilai koefisien yang didapatkan sebesar 0.007154746 akan tetapi pengaruh Pembelajaran Produk Kreatif dan Kewirausahaan tidak berpengaruh secara signifikan terhadap Minat Berwirausaha, karena terlihat dari nilai probabilitasnya 
sebesar 0.955973881 lebih besar dari nilai alpha $(0,05 / 5 \%)$.

\section{KESIMPULAN}

\section{Simpulan}

Berdasarkan hasil penelitian yang sudah dipaparkan pada bab sebelumnya, dapat diperoleh kesimpulan sebagai berikut:

1. Bahwa pembelajaran produk kreatif siswa dan kewirausahaan yang berlangsung di SMK Negeri 1 Mandor sudah sesuai di laksanakan, terlihat dari nilai rata-rata jawaban siswa sebesar 70,41 (kategori tinggi).

2. Bahwa minat berwirausaha siswa kelas XII di SMK Negeri 1 Mandor sudah tinggi, terlihat dari nilai rata-rata jawaban siswa sebesar 70,72 (kategori tinggi). Berarti minat berwirausaha siswa sudah terbangun sejak dini dan diharapkan akan dapat dikembangkan setelah menyelesaikan sekolah.

3. Bahwa Pembelajaran Produk Kreatif dan Kewirausahaan berpengaruh positif terhadap Minat Berwirausaha, terlihat dari nilai koefisiennya sebesar 0.007154746 akan tetapi pengaruh Pembelajaran Produk Kreatif dan Kewirausahaan tidak berpengaruh secara signifikan terhadap Minat Berwirausaha, karena terlihat dari nilai probabilitasnya sebesar 0.955973881 lebih besar dari nilai alpha $(0,05 / 5 \%)$.

\section{Saran}

Berdasarkan hasil penelitian yang sudah diperoleh, adapun saran yang dapat diberikan adalah sebagai berikut:

1. Guru pengampu mata pelajaran Produk Kreatif dan Kewirausahaan diharapkan menerapkan strategi khusus (yang cocok) dalam pelaksanaan pembelajaran agar siswa dapat menyerap materi Produk Kreatif dan Kewirausahaan yang diajarkan dengan maksimal dan tepat sasaran.

2. Guru dan siswa dapat melaksanakan praktik-praktik dalam pembelajaran Produk Kreatif dan Kewirausahaan yang berperan dalam membentuk jiwa wirausaha siswa.

3. Guru pengampu pelajaran dapat melaksanakan Pembelajaran Produk Kreatif dan Kewirausahaan di sekolah dengan memberikan gambaran yang sesuai dengan tuntutan dunia kerja, guna meningkatkan rasa minat berwirausaha siswa.

\section{DAFTAR PUSTAKA}

Alma, Buchari. (2013). Kewirausahaan, Cetakan ke 19. Bandung: Alfabeta. 
Arifin. (2010). Evaluasi Pembelajaran.

Bandung: Remaja Rosdakarya.

Slameto. (2010). Belajar dan Faktorfaktor yang Mempengaruhinya. Jakarta: Rineka Cipta

Sugiyono. (2019). Metode Penelitian Pendidikan (Pendekatan
Kuantitatif, Kualitatif dan R\&D). Bandung: Alfabeta.

Wibowo, Agus. (2011). Pendidikan Kewirausahaan, Cetakan ke 1. Yogyakarta: Pustaka Pelajar. 